\title{
Phytoplankton colonization by bacteria: encounter probability as a limiting factor
}

\author{
Dolors Vaqué, Carlos M. Duarte, Celia Marrasé \\ Instituto de Ciencias del Mar, C.S.I.C., Paseo Nacional s/n, 08003 Barcelona, Spain
}

\begin{abstract}
Use of algal surfaces as substrate for bacterial growth requires colonization of the algal surface. Based on a study of the dynamics of epialgal bacteria during a bloom episode of an enclosed phytoplankton community, we suggest that the colonization process is partially limited by the algabacterium encounter probability. This assertion is based on the demonstration that $86 \%$ of temporal variability in the average number of epialgal bacteria per algal cell can be explained by changes in the abundance of algae and free bacteria, that together constrain the alga-bacterium encounter probability. Encounter probability should, therefore, be of paramount importance for bacterial attachment to particles in the sparser communities inhabiting the oligotrophic sea. We postulate that one of the advantages of maintaining a dense, albeit not very active, bacterial population in the sea should be to maximize the probability of encountering algae or other patchy sources of organic carbon.
\end{abstract}

\section{INTRODUCTION}

Planktonic bacteria comprise free and attached bacteria, both dependent on the exogenous supply of organic carbon for growth. However, free and attached bacteria may differ with respect to the regulation of their abundance and activity (Hoppe 1984). While the abundance and growth of free bacteria appear to increase in the presence of a productive and abundant phytoplankton population (Bird \& Kalff 1984, Cole et al. 1988), the relationship between attached bacteria and phytoplankton is elusive (Fukami et al. 1983, Hoppe 1984, Egan 1987). Bacteria attached to algae often (particularly in oligotrophic environments) appear to be stimulated by an enhanced carbon supply from their host algae (Kogure et al. 1982, Albright et al. 1986, Egan 1987), although some evidence of an inhibitory influence has been obtained (cf. Cole 1982). However, the bacterium must first approach the algal surface to experience these interactions.

While bacteria apparently have mechanisms (e.g. chemokinesis; Jackson 1987) that enable them to colonize phytoplankters, recent studies suggest that these mechanisms are limited to bacteria very close to algal cells (Mitchell et al. 1985, Jackson 1987). Clearly, the probability of a bacterium being within the distance range necessary to colonize phytoplankton depends on the densities of both algae and free bacteria. Therefore, we hypothesize that the number of epialgal bacteria per algal cell should be positively related to the densities of both free bacteria and algae.

Here we examine whether this prediction could account for the patterns of change in the abundance of epialgal bacteria observed along a phytoplankton bloom (formation and collapse) of an enclosed marine plankton community. We chose to examine a phytoplankton bloom because it (1) encompasses the time scale appropriate to cover broad changes in phytoplankton physiological condition and growth rate (Harris 1986), and (2) comprises the variation in algal and free bacteria abundances necessary for our purposes.

Because of the difficulties in monitoring specific plankton communities in the sea (Brown \& Hutchings 1987), we used a natural plankton community enclosed in a microcosm. We followed the time-course of the abundances of algae, free bacteria, and the mean number of epialgal bacteria per algal cell.

\section{METHODS}

We enclosed our plankton community in quadruplicate $30 \mathrm{l}$ microcosms (Estrada et al. 1987) filled with seawater from the Masnou harbour (NE Barcelona). The microcosms were filled with water filtered through a $150 \mu \mathrm{m}$ netting to remove large zooplankters. Micro- 
cosms were kept at $20^{\circ} \mathrm{C}$, and received ca $270 \mu \mathrm{E} \mathrm{m} \mathrm{m}^{-2}$ $\mathrm{s}^{-1}$ with a $12: 12 \mathrm{~h}$ illumination cycle. Water samples were collected every $12 \mathrm{~h}$ at the onset of the dark and light periods, until phytoplankton density stabilized following bloom collapse ( $9 \mathrm{~d})$.

On each sampling occasion, we collected water from each of the 4 microcosms and analysed it to determine phytoplankton and bacterioplankton (free and attached to algae) density. Algal density was determined by inverted microscopy on samples fixed with Lugol. Free bacteria were separated from bacteria attached to particles by centrifugation at ca $600 \times \mathrm{g}$ for $10 \mathrm{~min}$; this we found to be the minimum at which no algae could be found in $10 \mathrm{ml}$ supernatant samples. The density of free bacteria was then estimated by counting the bacteria in an aliquot of the supernatant using epifluorescence microscopy (Nikon-ET microscope) following acridine orange staining and filtration through pre-stained (Sudan Black) $0.2 \mu \mathrm{m}$ Nuclepore filters (Hobbie et al. 1977).

The average number of attached bacteria per algal cell was obtained by filtering the pellet resuspended with $0.2 \mu \mathrm{m}$-filtered distilled water through a $2.0 \mu \mathrm{m}$ Nuclepore filter and then counting the number of bacteria attached to individual algal cells using epifluorescence microscopy. We counted at least 400 free bacteria and the bacteria attached to 50 to 100 randomly selected algal cells. Because we consider that unidentifiable particles belonged to the detrital fraction, rather than to the phytoplankton community, we considered only those cells that could be unambiguously identified as algae to estimate the number of epialgal bacteria per algal cell.

We examined the association between variables using correlation analysis, to compare pairs of variables, or multiple regression analysis, to establish the relationship between one variable and several others. When the correlation between 2 variables was sus- pected to be influenced by colinearity with a third one, we attempted to remove this effect by calculating the partial correlations between them (Steel \& Torrie 1960).

\section{RESULTS}

The temporal dynamics of the enclosed phytoplankton community were similar to those observed in previous experiments with these microcosms (Estrada et al. 1987). Phytoplankton responded to confinement by exponential growth (Fig. 1), after a lag phase of $2 \mathrm{~d}$, until nutrient depletion (initial $\mathrm{NO}_{3}+\mathrm{NO}_{2}$ concentration $=8.9 \mu \mathrm{M} ; \mathrm{NO}_{3}+\mathrm{NO}_{2}$ concentration at peak biomass $=0.10 \mu M)$. The phytoplankton community was dominated by diatoms (Skeletonema costatum, Leptocylindrus danicus) and small flagellates. The abundance of free bacteria increased following phytoplankton bloom collapse (Fig. 1).

We predict that the extent of bacterial colonization of algal surfaces should increase with increasing both bacterial and algal abundances. Our data, however, indicate a negative correlation between the extent of algal colonization by bacteria and algal density $(r=-0.55, p<0.05)$. This negative correlation, however, is influenced by the strong colinearity between the abundance of free bacteria and algae $(r=-0.74$ $p<0.05$ ) that results from low algal density when the density of free bacteria is high (Fig. 1). This effect was avoided by calculating partial correlations (where the covariable is held constant) between the number of epialgal bacteria per algal cell and the abundance of algae and free bacteria. The positive partial correlations obtained between epialgal and both the algal (partial $r=0.53, p<0.05$ ) and free bacteria (partial $r=0.90, p<0.001$ ) abundance confirm that the negative correlation to algal density found was indeed a

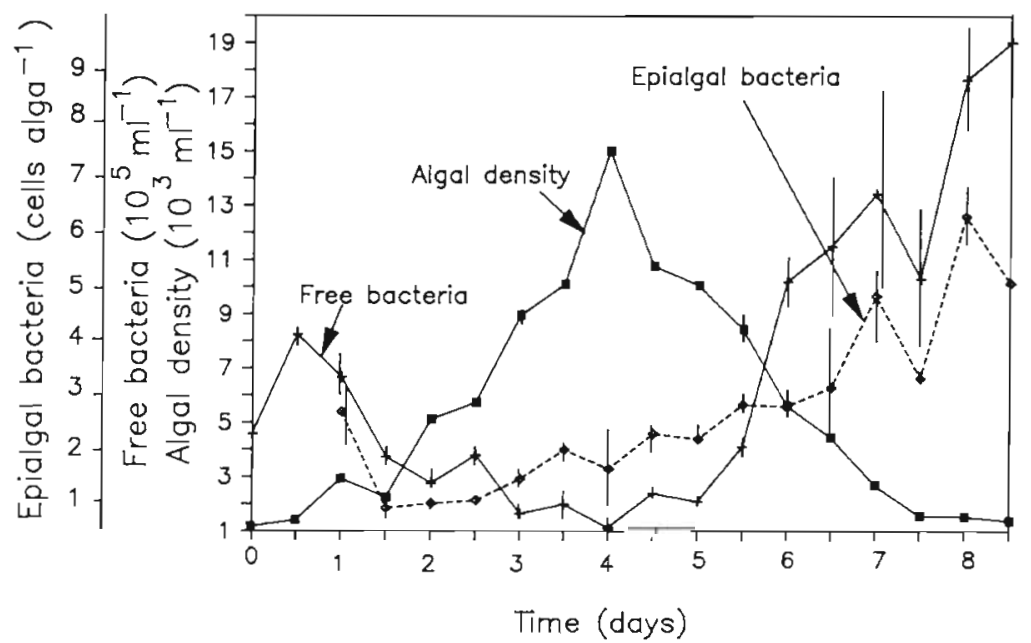

Fig. 1. Time course of the density of algae and free bacteria, and the number of attached bacteria per algal cell. Vertical bars represent $\pm \mathrm{SE}$ 
Consequence of the increase in free bacteria as phytoplankton abundance decreased (Fig. 1).

That the partial correlations between the number of attached bacteria per algal cell and algal density ( $A$, cells $\mathrm{ml}^{-1}$ ) and free bacteria density $\left(B, 10^{5}\right.$ bacteria $\mathrm{ml}^{-1}$ ) are positive indicates that the extent of algal colonization by bacteria is, as we hypothesized, simultaneously influenced by both algal $\left(A\right.$, cells $\mathrm{ml}^{-1}$ ) and free bacteria ( $B$, cells $\mathrm{ml}^{-1}$ ) concentrations. Thus, we developed a multiple regression equation to represent this relation:

$$
\begin{gathered}
\text { Epialgal bacteria cell } l^{-1}=-0.18+0.30 \times \\
10^{-5} \mathrm{~B}+0.13 \times 10^{-3} \mathrm{~A} \\
R^{2}=0.86 ; N=16 ; \mathrm{SE}_{\text {estimate }}=0.61 ; \\
F=41.6 ; p<0.0001
\end{gathered}
$$

This regression equation accounted for $86 \%$ of the variability in the extent of algal colonization by bacteria (Fig. 2). The error remaining after this multiple regres-

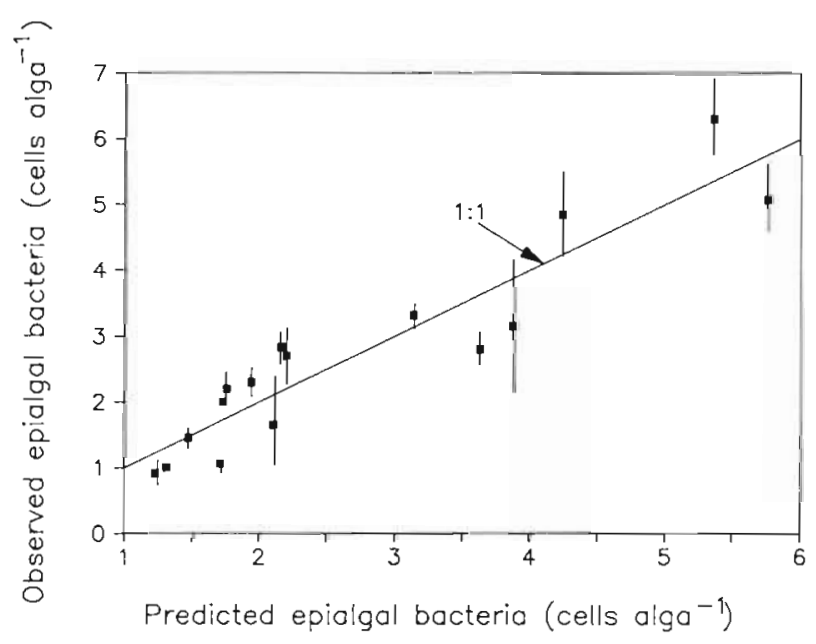

Fig. 2. Relation between number of attached bacteria per algal cell and values predicted from a multiple regression based on the densities of algae and free bacteria (Eq. 1). Vertical bars represent $\pm \mathrm{SE}$

sion $\left(\mathrm{SE}_{\text {estumate }}=0.61\right)$ is not much larger than that associated with the estimation of the number of epialgal bacteria per algal cell (average SE for all dates $=0.40$; Fig. 2).

\section{DISCUSSION}

Our results support the hypothesis that the extent of algal colonization by bacteria depends on the abundances of algae and free bacteria. This would be expected if algal colonization by bacteria were limited by the encounter probability.

The importance of deterministic colonization processes, such as chemokinetic search of algal cells
(Azam \& Ammerman 1984, Mitchell et al. 1985, Jackson 1987) upon algal colonization by bacteria should be small. The reasons for this assertion are that these mechanisms appear to be effective only at short range (i.e. 10 to 20 m from the algal cell, Jackson 1987; but see Mitchell et al. 1985, Ishida et al. 1986), and for algae $>10 \mu \mathrm{m}$ diameter, and bacteria $>0.5 \mu \mathrm{m}$ diameter (Jackson 1987). However, the average distance between bacteria in our experiment (ca $200 \mu \mathrm{m}$ ) was large compared to the mean algal cell diameter ( 5 to $10 \mu \mathrm{m})$, such that most bacteria would be too far from the nearest algal cell for active colonization, and furthermore most of our algae and bacteria were smaller than $10 \mu \mathrm{m}$ and $0.5 \mu \mathrm{m}$ diameter, respectively. These constraints should be even more acute in oligotrophic seas, where average distances between viable bacteria may be as large as $1000 \mu \mathrm{m}$ (Ishida et al. 1986), and small bacteria (Sieracki et al. 1985) and algae (Stockner 1988) are numerically dominant.

It is difficult, however, to provide a reliable estimate for the critical bacterial and algal densities necessary for effective chemokinetic colonization, because there is considerable disagreement regarding the net speed of bacteria (Azam \& Ammerman 1984, Mitchell et al. 1985, Ishida et al. 1986, Jackson 1987) in relation to the sinking velocity of particles or algal cells (Mitchell et al. 1985). Nevertheless, the finding that the encounter probability appears to limit algal colonization by epialgal bacteria within the relatively dense bacterial and phytoplankton populations in our microcosm suggests that this problem must be even more acute in the open sea. Bacterial chemokinesis, therefore, may be more useful 'to keep a bacterial cell near a source of organic material once it has arrived there by chance' (Bell \& Mitchell 1972) or to avoid algae excreting inhibitory products, than as a colonization device.

The error of the relationship between the number of epialgal bacteria per cell and both bacterial and algal abundances (Eq. 1) is similar to the error among replicates. However, our analysis (based on average values alone) considers the plankton and bacterial populations as homogeneous populations, and implicitly assumes all algae to be equally susceptible to colonization, whereas in fact we observed that some algal species (e.g. Scrippsiella trochoidea, Dinophyceae) are colonized to a greater extent than others (e.g. Asterionella japonica, Bacillariophyceae). Indeed, differences in surface characteristics and the production of inhibitory substances among different algal species may critically influence the success of bacterial attachment (Cole 1982, Egan 1987).

The heterogeneity of the plankton assemblage studied may, thus, be responsible for the sizeable among-algae variability in the number of attached bacteria (error bars in Fig. 1). Other factors that may gener- 
ate among-algae variability in the number of attached bacteria are (1) differences in algal cell size, which should influence the encounter probability; and (2) differences in the time the cells are exposed to colonization, for active cell division should decrease the average time the cells are exposed to bacterial colonization.

It is generally observed that an important fraction $(40$ to $90 \%$ ) of planktonic bacteria are not metabolically active (Hoppe 1984, Riemann et al. 1987), but may rapidly increase their activity upon an improvement in growth conditions (Ducklow \& Hill 1985). This behavior contrasts with the response of most other organisms to adverse or limiting growing conditions, which involves mortality. An obvious advantage of this behavior is that since phytoplankton, which provides most of the carbon necessary for bacterial growth in the sea (e.g. Albright et al. 1986), is found in low and variable concentrations in the sea, the maintenance of the highest possible bacterial density maximizes the probability of colonizing the phycosphere (as well as any other patchy source of organic carbon). This strategy would be comparable to that of parasitic ticks that respond to the very low probability of encountering a homeotherm by sustaining large densities and resting in a dormant stage, where only a small activity associated to basal metabolism and the energy requirements of their thermal detection system can be measured (Kim 1985).

The maintenance of dense and modestly active bacterial populations would partially overcome the bottleneck of encounter rates, which may be critical where bacterioplankton depend on resources that are patchy and spatially or temporally rare.

Acknowledgements. This research was supported by grant PR84-0061 of the CAICYT and the Instituto de Ciencias del Mar We thank Rosa Ras for enthusiastic technical assistance, and Dr F. Vallespinós for encouragement and helpful criticisms.

\section{LITERATURE CITED}

Albright, L. J., McRae, S. K., May, B. E. (1986). Attached and free-floating bacterioplankton in Howe Sound, British Columbia, a coastal marine fjord-embayment. Appl. environ. Microbiol. 51: 614-621

Azam, F. Ammerman, J. W. (1984). Cycling of organic matter by bacterioplankton in pelagic marine ecosystems: microenvironmental considerations. In: Fasham, M. J. R. (ed.) Flows of energy and matter in marine ecosysems. Plenum Press, New York, p. 345-360

Bell, W., Mitchell, R. (1972). Chemotactic and growth responses of marine bacteria to algal extracellular products. Biol. Bull. mar biol. Lab., Woods Hole 143: 265-277

This article was submitted to the editor
Bird, D. F., Kalff, J. (1984). Empirical relationships between bacterial abundance and chlorophyll concentration in fresh and marine waters. Can. J. Fish. Aquat. Sci. 41: 1015-1023

Brown, P. C., Hutchings, L. (1987). The development and decline of phytoplankton blooms in the Southern Benguela upwelling system. 1. Drogue movements, hydrography, and bloom development. S. Afr. J. mar. Sci. 5: 357-391

Cole, J. J. (1982). Interactions between bacteria and algae in aquatic ecosystems. Ann. Rev. Ecol. Syst. 13: 291--314

Cole, J. J., Findlay, S., Pace, M. (1988). Bacterial production in fresh and saltwater ecosystems: a cross-system overview. Mar. Ecol. Prog. Ser. 43: 1-10

Ducklow, H. W., Hill, S. M. (1985). Tritiated thymidine incorporation and the growth of heterotrophic bacteria in warm core rings. Limnol. Oceanogr. 30: 260-272

Egan, B. (1987). Marine microbial adhesion and its consequences. In: Sleigh, M. A. (ed.) Microbes in the sea. Ellis Horwood, Chichester, p. 220-238

Estrada, M., Alcaraz, M., Marrase, C. (1987). Effects of turbulence on the composition of phytoplankton assemblages in marine microcosms. Mar Ecol. Prog. Ser. 38: 267-281

Fukami, K., Simidu, U., Taga, N. (1983). Change in a bacterial population during the process of degradation of a phytoplankton bloom in a brackish lake. Mar. Biol. 76: 253-255

Harris, G. P. (1986). Phytoplankton ecology. Structure, function, and fluctuation. Chapman and Hall, New York

Hobbie, J. E., Daley. R. J., Jasper, S. (1977). Use of nuclepore filters for counting bacteria by fluorescence microscopy Appl. environ. Microbiol. 33: 1225-1228

Hoppe, H.-G. (1984). Attachment of bacteria: advantage and disadvantage for survival in the aquatic environment. In: Marshall, K. C. (ed.) Microbial adhesion and aggregation. Springer-Verlag, New York, p. 283-301

Ishida, Y., Eguchi, M., Kadota, H. (1986). Existence of obligately oligotrophic bacteria as a dominant population in the South China Sea and the West Pacific Ocean. Mar. Ecol. Prog. Ser. 30: 197-203

Jackson, G. A. (1987). Simulating chemosensory responses of marine microorganisms. Limnol. Oceanogr. 32: 1253-1266

Kim, K. C. (1985). Coevolution of parasitic arthropods and mammals. Wiley, New York

Kogure, K., Simidu, U., Taga, N. (1982). Bacterial attachment to phytoplankton in sea water. J. exp. mar. Biol. Ecol. 56: 197-204.

Mitchell, J. G., Okubo, A., Furhman, J. A. (1985). Microzones surrounding phytoplankton form the basis for a stratified marine ecosystem. Nature, Lond. 316: 58-59

Riemann, B., Bjornsen, P. K., Newell, S., Fallon, R. (1987). Calculation of cell production of coastal marine bacteria based on measured incorporation of ${ }^{3} \mathrm{H}$-thymidine. Limnol. Oceanogr. 32: 471-476

Sieracki, M. E., Johnson, P. W., Sieburth, J. M. (1985). Detection, enumeration, and sizing of planktonic bacteria by image-analyzed epifluorescence microscopy. Appl. environ. Microbiol. 49: 799-810

Steel, R. D., Torrie, J. H. (1960). Principles and procedures in statistics. McGraw-Hill, New York

Stockner, J. G. (1988). Phototrophic phytoplankton: an overview from marine and freshwater ecosystems. Limnol. Oceanogr. 33: 705-775

Manuscript first received: October 11, 1988

Revised version accepted: March 6, 1989 